\title{
Assessment of the Effects of Emerging Grazing Policies on Land Degradation in Nigeria
}

\author{
${ }^{1}$ TAIYE, OA; ${ }^{2}$ DAUDA, MM; ${ }^{3}$ EMMANUEL, AO \\ ${ }^{1 \& 2}$ Department of Geography, Nigerian Defence Academy, Kaduna \\ ${ }^{3}$ Department of Geography, Bayero University, Kano \\ Department of Geography, Nigerian Defence Academy, \\ PMB 2109, Kaduna State, Nigeria, 2821 \\ Correspondence: E-mail: taiyeadewuyi@yahoo.com,Tel: +234803700
}

\begin{abstract}
This study examines the effects of the emerging grazing policies on land degradation in Nigeria using soil, vegetation and sustainability as variables for the assessment. Data was acquired and analyzed and the results show that conflicts between farmers and herders occur all over Nigeria. The consequences of these affect lives, properties and the environment. The country now has approximately 210 persons and 180 grazing animals per kilometer square of land and 15,000 persons and 12,500 grazing animals per kilometer square of water. With the population of both man and grazing animals increasing at very high rates, the need for both food and fodder is becoming more desperate. This impact negatively on the soil, vegetation and water when there is intensive grazing without proper conservation plans in place. This study therefore, suggests the adoption of the emerging grazing policies, but with the modification that will build in agroforestry system of agriculture to suit each ecological zone. This is with a view to solving socio-economic problems of farmers and herders, and also to protect the environment from degradation. @ JASEM

https://dx.doi.org/10.4314/jasem.v21i6.32
\end{abstract}

Key words: Grazing reserve, Land degradation, Livestock production, Ranching, Sustainability.

Globally, managed grazing lands comprise the largest land use, estimated to cover about $25 \%$ of Earth's land surface (Asner et al., 2004). The extensive area covered by rangelands makes them an essential resource for maintaining biodiversity and a source of livelihood, especially for rural communities. Grazing reserves in Nigeria started during the pre-colonial era. The attempt by the British in 1940 to separate the grazing land from the farm land, however, faltered because the Europeans imposed land use controls divorced from economic and demographic dynamics in the pastoral system (Frantz, 1981).

Free grazing has a number of ecological effects which may be either positive or negative. Yet, grazing could be beneficial to the ecosystem (Goldschmidt, 1980). It is advantageous towards the soil and grasses, promoting nutrient dense soil and stimulating the growth of plant varieties through the droppings of the animals. Through grazing, livestock encourages plant growth thereby increasing forage production. Furthermore, the animals' urine and feces help to recycle nitrogen, phosphorus, potassium and other plant nutrients and return them to the soil. It also acts as rations for insects and organisms found within the soil. These organisms can aid in carbon sequestration and water filtration. These nutrients and organisms are necessary for soil to be prosperous and capable of production at a very high level.

However, grazing has significant negative impacts on local biodiversity, such as destruction of native vegetation, soils and stream banks damage, increased soil erosion through increase in runoff and contamination of waterways with fecal waste. After decades of livestock grazing, once-lush streams and riparian forests have been reduced to flat, dry wastelands; once-rich topsoil has been turned to dust, causing soil erosion, stream sedimentation and wholesale elimination of some aquatic habitats (Adewuyi and Mustapha, 2017).

Cattle grazing in Nigeria have resulted in severe environmental degradation which has affected agricultural production, health standard and engendered some security risks including socio-cultural conflicts between the original inhabitants of the area and the nomadic cattle rearers (Tarawali \& Pamo, 1992). As noted by Tarawali \& Pamo (1992), the people of Nigeria are mainly farmers producing food crops such as rice, yams, maize, millet, cassava and beans among many crops, in large quantities due to the favorable biophysical conditions of the landscape. The land tenure system practiced in the country empowers ownership of land by individuals and families for the purpose of food production. Each family or individual strives to conserve some portions of its/his land for cultivation and ensure the security of the farms from domestic animals. To this extent, during planting seasons, grazing of animals is restricted to certain agreed areas different from crop fields so as to avoid the damage of the latter by the animals. In most areas strict rules exist to check this practice. 
It is therefore pertinent to study the emerging grazing policies in Nigeria and their effects toward environmental degradation. Therefore, the objective of this study is to synthesize existing knowledge on emerging grazing policies and their effects on land degradation in Nigeria.

\section{MATERIALS AND METHODS}

Study Area: Nigeria is located between latitude $4^{\circ} 20^{\prime}$ and $13^{\circ} 57^{\prime}$ North of the Equator and longitude $2^{\circ} 40^{\prime}$ and $14^{\circ} 40^{\prime}$ East of the Greenwich Meridian (Figure 1). The elevation rise from zero at the coast to $2418 \mathrm{~m}$ at the highest point in Taraba state. The country has a land area of $923,768 \mathrm{~km}^{2}$ of which $910,768 \mathrm{~km}^{2}$ is land and the rest $13,000 \mathrm{~km}^{2}$ is water. It has a massive $853 \mathrm{~km}$ coastline with the Atlantic Ocean, and different vegetation covers, starting with mangrove forest in the coastal area, followed by rain forest cover mostly in the southern parts and then massive savanna region varying in type from Guinea savanna in the middle belt, to Sudan in the northern part and Sahel savanna at the extreme northern part of Nigeria.

Throughout the country there are abundant trees and grasses in different proportions. The rainfall likewise varies from the coast with about $3,000 \mathrm{~mm} /$ per annum to about $500 \mathrm{~mm}$ in the far north, with similar pattern in terms of length of rainy season which is almost all year round along the coast to 3 months in the Sahel area of the country. The temperature is generally warm averaging $25^{\circ} \mathrm{c}$ to $28^{\circ} \mathrm{c}$ making the country conducive for year round farming and grazing, but with lower temperature of $13^{\circ} \mathrm{c}$ in the north during the harmattan in December and $40^{\circ} \mathrm{c}$ during the hot weather in April both in the far north. The soil in Nigeria is general broad in types and quality but good enough to support existing agricultural practices.

Data Collection : The main information utilized are the laws promulgated by three states on open grazing between 2016 and 2017 and the projected population of man and grazing animals in Nigeria (The Guardian, 2016; Hunkuyi, 2017 \& Premium Times, 2017).

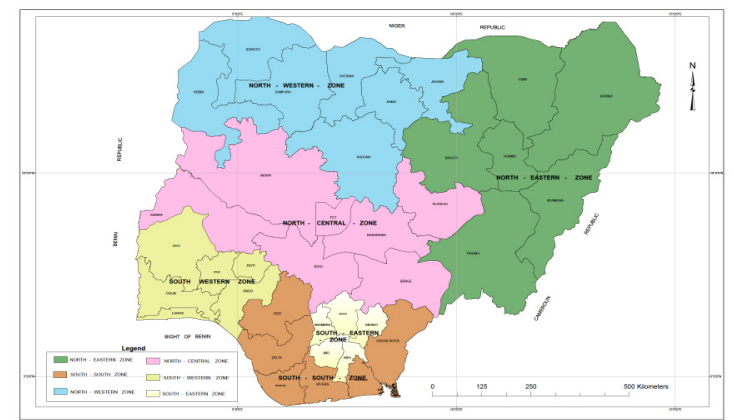

Fig 1: Geopolitical Zones of Nigeria

Source: Geography Dept., NDA, 2017.

Data Analysis: The method adopted was basically impact assessment based on comparative study. Emphasis in the analysis and discussion was given to existing socioeconomic challenges, Land Use Acts, land scarcity, climatic variations and other environmental challenges across the nation.

\section{RESULTS AND DISCUSSION}

This study has revealed that farming and grazing result in the depletion of the quality of the environment in various ways. In the process of farming a lot of vegetation cover is removed with the view to obtain space for cultivation thereby adding to the already existing environmental problems. It is believed that a substantial number of these human activities result in the depletion of environmental qualities and consequently leads to environmental degradation.

Data on grazing through physical observation of these environments reveal the extent of the damage caused by lack of proper government policies on grazing. Other data concerning environmental degradation mitigation policies are elicited through field/farm inspection and discussion with some staff in relevant ministries and organizations.

The assessment on the impacts of human activities on the environment, are mainly deforestation and overgrazing, which negatively affect environmental resources. Therefore going by this finding it is clear that human activities of over 190 million people and over 160 million grazing animals on $910,000 \mathrm{~km}^{2}$ land translates to approximately 210 person and 180 grazing animals per square kilometer of land. Similarly, about 15,000 persons and 12,500 grazing animals will depend 
on a space of square kilometer of water. This, no doubt, will impact negatively on the environment (soil, vegetation and water) wherever there is intensive grazing without proper conservation plan in place.

\section{Implications of Unplanned Grazing and Ranches on the} Land

Soil Health: Soils with good physical and chemical characteristics are essential in maintaining productivity in terrestrial ecosystems and driving processes that sustain environmental quality. The biological, physical, and chemical properties of soil can be modified by livestock grazing. It has been demonstrated that intensive livestock grazing profoundly affects soils as it increases soil compaction, soil erosion and loss, decreases soil organic matter, affect nutrient cycling and reduces water infiltration (Belsky and Blumenthal, 1997). Livestock grazing causes disturbances to surface soils and can influence savanna ecosystem productivity and fertility by altering the soil physical and chemical properties, causing land degradation.

Livestock grazing can compact soil particularly under high grazing intensity (Asner et al., 2004). Most studies have reported significant increases in bulk density in grazing land, especially in finer textured soils and in the soil surface layers, caused by hoof traffic of livestock. Compaction is directly related to soil productivity because it reduces water and air movement into and through the soil, and therefore reduces water availability to plant roots, restricts and reduces soil microorganisms, reduces soil nutrient availability and increase soil surface runoff and soil erosion (Asner $e t$ al., 2004). The soil surface erosion has profound effects on soil productivity and ecosystem functions because microorganisms, organic matter, soil fauna and roots are all concentrated in the surface soil and once they are lost it may be very difficult to reverse; where and when it is done, it is normally at a very high price in terms of cost, effort, health, life and stress.

Research has shown that soil erosion increases with livestock grazing intensity (Belsky and Blumenthal, 1997). Studies conducted in grazing land and ungrazed enclosures have reported significantly higher sediment production rates in many plant communities under grazing land, and production was observed to be significantly related to grazing intensity. Heavy grazing reduces vegetation cover and limits organic matter inputs into the soil. This subsequently affects soil structure stability, resistance to rainfall impact, infiltration rate and soil microbial activity. Overgrazing caused by livestock grazing reduces plant biomass accumulation and causes a shift in plant species composition by replacing highly palatable grass species with their unpalatable counterparts.

The shift in species composition can affect soil fertility because of changes in root biomass and quality of organic matter, and decrease soil's capacity to sequester carbon. Studies have shown that soil nutrient depletion reduces the primary production of rangelands which in turn affects their carrying capacity. The authors of this study believe that livestock grazing management systems do not affect soil properties in savanna ecosystems differently, because soil texture, bulk density and $\mathrm{pH}$ do not differ between management systems despite differences in grazing intensities, though significant differences may occur occasionally between and within the study sites. Other comparative studies found no significant effect of livestock grazing management on soil texture, bulk density and $\mathrm{pH}$. Some found no relationship between soil bulk density and livestock stocking rates, while some found no significant differences in soil chemical properties (for example, $\mathrm{pH}$ ) between grazed communal land and ungrazed land. The results of these studies could suggest that livestock grazing systems do not have significant effect on soil properties especially in sandy regions (Bennett et al., 2010). However, Nigeria is not entirely covered by sandy soil region particularly in the middle belt and the southern part of the country, therefore one should tread softly.

Vegetation: Savannas in Africa are largely exploited through livestock grazing, and the grazing intensity (removal of plant biomass by livestock) influences their sustainability. Most grasses in savanna ecosystems are fairly tolerant to grazing; however, prolonged intense grazing eventually leads to shift in species composition and reduction in grass biomass especially when soil nutrients are depleted. Overgrazing affects the botanical composition and species diversity by depressing the vigour and presence of dominant species, which then enables colonization by less competitive, plant species which are grazing tolerant. Selective grazing of palatable herbaceous plants by livestock enhances the growth of annuals and unpalatable herbaceous plants as 
well as woody plants resulting in the decline of palatable species (Bilotta et al., 2007).

Woody plant encroachment has been widespread in grasslands and savanna ecosystems worldwide (Archer et al., 2001). Bush encroachment is an important indicator of land degradation which has become a global concern. Woody plant encroachment into grassland-dominated savannas has contributed to a decrease in the productivity of rangelands, and jeopardizes biodiversity in grasslands, which threatens the sustainability of pastoral, subsistence and commercial livestock grazing. Some savanna landscapes are completely encroached by woody species, while in other savanna areas the process is in progress (Abule et al., 2005).

Factors that contribute to bush encroachment are poorly understood. However, overgrazing, anthropogenic reductions in fire regimes, frequent droughts, and climate change are suspected to facilitate the process. The increase in bushy vegetation in rangelands threatens livestock production in the savannas because encroaching woody species suppress palatable grasses and herbs through competition for soil moisture and nutrients (Cole and Brown, 1976).

However, encroaching leguminous woody plants such as Acacia mellifera may enrich nutrient poor sandy soils in dry savannas through nitrogen fixation. Research has shown that soils under the canopy of tree species such as A. mellifera have higher levels of nitrogen, organic matter and calcium than soils distant to trees. Some woody plants are also an important fodder resource especially during dry periods. Therefore, a management aim of bush encroached rangelands could be selective thinning of woody vegetation to reduce the grass-tree competition, whilst retaining the beneficial effects of soil enrichment from leguminous tree and shrub species. Bush encroachment is an environmental problem in both ranches and communal grazing land despite the difference in grazing intensity between the two grazing management systems (Dougill et al., 1999).

Sustainability of the New Grazing Policies: Ademosun (1976) lists some of the gains from the grazing reserves as easing seasonal migration, improving the quality of herds, multiplying outlet for bovine product, and enhancing access to extension and social services. The grazing reserve also encourages the uniform deployment of the cattle. It is in view of these benefits that the Federal Government is set to rehabilitate the 414 grazing reserve centres and stock routes across the country.

However from this study, there is the need to embraced grazing reserve and ranching with caution, so as not to solve one problem and aggravate another. The approach of one of the states which emphasizes publicity and thorough education before embarking on it should be applauded and encourage throughout Nigeria. Also, the new grazing policy tackles socio-economic challenges which is commendable, but environmental challenges are also paramount. As a result of these uncertainties about the environmental and socio-political impacts of this policy, this study agrees with the expressed sustainable development benefits of grazing reserves since they emphasize environmental protection which is paramount in the course of any economic activities of any sector, but suggests proper caution and modification in its adoption.

More importantly, for this new approach to succeed, it must address both the short and long term socioeconomic problems and environmental challenges that could arise (Bekure, 1993). It is in view of this that this study will suggest the modification of the policy by introducing agroforestry system which is the integration of animal husbandry, cropping and forestry that suit the ecological zones of the country. It is the beliefs of this study that, when this is done, and with the benefits of all year round income (from crops, animals and their by-products and woods), improved vegetation cover (trees and grasses) and better water regime, there is going to be comprehensive sustainable growth. This may even succeed beyond solving the two earlier mentioned problems and begin to create appropriate environment for sustainable economic development through the emergence of small and medium scale industries in the agricultural sector across the country. This also will solve the teeming unemployment problems in the country with the tendency of reducing crime too (Bekure, 1983; Adewuyi and Mustapha, 2017). However, the provision of livestock corridors would not be necessary; buyers should go to where the livestock of interest is. Livestock movement is primarily related to searching for green pasture. 
Conclusion: This study has revealed that overgrazing and prolonged poorly managed rangelands can lead to the removal of desirable plant species, decrease water infiltration into soil, increase soil erosion, reduce soil nutrients and alter the plant community composition to a less desirable state leading to land degradation. As a result, agroforestry systems should be adopted because of their accommodation of animal husbandry, forestry and cropping simultaneously. However, these systems shall be modified to suit different ecological zones of the country to protect the land from further degradation by herd men.

\section{REFERENCES}

Abel, N (1997). Mismeasurement of the productivity and sustainability of African communal rangelands: A case study and some principles from Botswana. Ecol. Econ. 23:113-133.

Abule, E; Smit GN; Snyman, HA (2005).The influence of woody plants and livestock grazing on grass species composition, yield and soil nutrients in the Middle Awash Valley of Ethiopia.

J. Arid. Environ.60:343-358.

Ademosun, A (1976). Livestock production in Nigeria: Our commissions and omissions, Inaugural Lecture Series 17 delivered at the University of Ife on February 291976. Ife: University of Ife Press.

Adewuyi, TO; Mustapha, IA (2017), Geo-spatial Analysis of forest reserves in northern Nigeria and its implications to the Environment and National Security.

Asner, GP; Elmore, AJ; Olander, LP; Martin, RE; Harris, AT (2004).Grazing systems, ecosystem response, and global change.Ann. Rev. Environ. Resour. 29:261-299.

Archer, S; Boutton, TW; Hibbard, KA (2001).Tree in grasslands: biogeochemical consequences of woody plant expansion. In: SchulzeHarrison E-D, SP: Heimann, M; Holland, EA; Lloyd, J; Prentice, IC; Schimel, D (Eds.). Global Biogeochemical Cycles in the Climate Systems. Academic Press, San Diego, pp. 115137.

Awogbade, M (1980). "Livestock development and range use in Nigeria." In the future of pastoral people: Proceedings of a conference held in Nairobi, August 4-8, 1980, by Institute of Development Studies. Nairobi: Institute of Development Studies, 325-333.

Bekure, S (1993). Livestock Development: Issues and Opportunities. Washington, D.C.: World Bank, 1993. Draft Report No. 12058UNI.

Belsky, AJ; Blumenthal, DM (1997).Effects of livestock grazing on stand dynamics and soil in upland forest of the interior west.Conserv.Biol.11(2):315-327.
Bennett, J; Ainslie, A; Davis, J (2010).Fenced in: Common property struggles in the management of communal rangelands in central Eastern Cape Province, South Africa. Land Use Pol. 27:340-350.

Bilotta, GS; Brazier, RE;Haygarth, PM; Donald, LS (2007).The impacts of grazing animals on the quality of soils, vegetation, and surface waters in intensively managed grasslands. $A d v$. Agron. Academic Press, pp. 237-280.

Cole, MM; Brown, RC (1976).The Vegetation of the Ghanzi Area of Western Botswana J Biogeogr. 3:169-196.

Dougill, AJ; Thomas, DSG; Heathwaite, AL (1999).Environmental change in the Kalahari: Integrated land degradation studies for non-equilibrium dryland environments. Ann. Assoc. Am. Geogr. 89:420-442.n

Frantz, C (1978). "Ecology and social organization among Nigerian Fulbe (Fulani)" In: Weissleder, W (ed) The nomadic alternative: Modes of interactions in African-Asian desert and steppes. Paris: Mouton Publishers.

Frantz, C (1980). "The open niche, pastoralism and sedentarization in the Mambila grasslands of Nigeria." In: Salzman, P. When nomads settle. Philip New York: Praeger.

Frantz, C (1981). "Fulbecontinuity and change underfive flags atop West Africa: Territoriality, ethnicity, stratification, and national integration." In: Galaty, J; Salzman, P (ed) Change and development in nomadic and pastoral societies, 89-115. Netherlands: E. J. Brill.

Goldschmidt, W (1980). "The failure of pastoral economic development program in Africa." In the future of pastoral people: proceedings of a conference held in Nairobi, august 4-8, 1980, by the institute of development studies. Nairobi: I.D.S., 1980, 101-117.

Hunkuyi, MI (2017). Nigeria: Taraba Governor signs anti-grazing law. Daily Trust of $26^{\text {th }}$ July 2017. hppt://www.allafrica.com/stories/201707260899.html.

Premium Times (2016) National Agricultural Sample Survey. hppt://www.premiumtimesng.com/regional/northcentral/2345050921.html.

Premium Times (2017) Obey Anti-grazing Law or leave Benue. hppt://www.premiumtimesng.com/regional/northcentral/2345050921.html.

Tarawali, G; Pamo, T (1992)"A Case for On-farm Trials of Fodder Bank on the Adamawa Plateau in Cameroon" G. Britain: Institute of Animal Research, Wakwa Centre Experimental Agriculture, 1992.

The Guardian (2017) Nigeria: The Ekitigrazing law. http://www.theguardiannewspaper.com 